\title{
Mapping Dynamics of Bacterial Communities in a Full-Scale Drinking Water Distribution System Using Flow Cytometry
}

\author{
Caroline Schleich ${ }^{1}$, Sandy Chan ${ }^{2,3,4}$, Kristjan Pullerits ${ }^{2,3,4}$, Michael D. Besmer ${ }^{5}$, \\ Catherine J. Paul 2,6 , Peter Rådström ${ }^{2}$ and Alexander Keucken 1,6,* \\ 1 Vatten \& Miljö i Väst AB, SE-311 22 Falkenberg, Sweden; Caroline.Schleich@vivab.info \\ 2 Applied Microbiology, Department of Chemistry, Lund University, P.O. Box 124, SE-221 00 Lund, Sweden; \\ Sandy.Chan@sydvatten.se (S.C.); kristjan.pullerits@tmb.lth.se (K.P.); catherine.paul@tvrl.lth.se (C.J.P.); \\ peter.radstrom@tmb.lth.se (P.R.) \\ 3 Sweden Water Research AB, Ideon Science Park, Scheelevägen 15, SE-223 70 Lund, Sweden \\ 4 Sydvatten AB, Hyllie Stationstorg 21, SE-215 32 Malmö, Sweden \\ 5 onCyt Microbiology AG, CH-8038 Zürich, Switzerland; michael.besmer@oncyt.com \\ 6 Water Resources Engineering, Department of Building and Environmental Engineering, Faculty of \\ Engineering, Lund University, P.O. Box 118, SE-221 00 Lund, Sweden \\ * Correspondence: alexander.keucken@vivab.info
}

Received: 9 September 2019; Accepted: 11 October 2019; Published: 15 October 2019

\begin{abstract}
Microbial monitoring of drinking water is required to guarantee high quality water and to mitigate health hazards. Flow cytometry (FCM) is a fast and robust method that determines bacterial concentrations in liquids. In this study, FCM was applied to monitor the dynamics of the bacterial communities over one year in a full-scale drinking water distribution system (DWDS), following implementation of ultrafiltration (UF) combined with coagulation at the drinking water treatment plant (DWTP). Correlations between the environmental conditions in the DWDS and microbial regrowth were observed, including increases in total cell counts with increasing retention time (correlation coefficient $R=0.89$ ) and increasing water temperature (up to 5.24-fold increase in cell counts during summer). Temporal and spatial biofilm dynamics affecting the water within the DWDS were also observed, such as changes in the percentage of high nucleic acid bacteria with increasing retention time (correlation coefficient $R=-0.79$ ). FCM baselines were defined for specific areas in the DWDS to support future management strategies in this DWDS, including a gradual reduction of chloramine.
\end{abstract}

Keywords: flow cytometry; biofilm; drinking water distribution system; ultrafiltration; coagulation; drinking water management

\section{Introduction}

Drinking water needs to be safe, esthetically acceptable, and not cause excessive damage to infrastructure. These aspects of water quality are impacted by microorganisms, the majority of which are bacteria that originate from the source water, are shaped by processes in the drinking water treatment plant (DWTP), and are contributed from biofilms in the drinking water distribution system (DWDS) during distribution [1-4]. A high bacterial cell concentration can lead to: Esthetic problems, such as discoloration of the water and/or changes in taste and odor; increased biocorrosion with concomitant high copper and iron concentrations in the water; and thus deterioration of the DWDS [5-7]. Growth of opportunistic pathogens such as Legionella ssp. in the drinking water can pose a severe health risk $[8,9]$. To counter these risks, the DWTP should control bacterial survival 
and regrowth in the DWDS, using methods like filtration, which limits the input of nutrients, and disinfection, using UV irradiation and chlorination $[4,10,11]$. Some bacteria, however, often remain in the drinking water after these and other treatments, and enter the DWDS [12]. The estimated bacterial concentration in most distributed drinking water is between $10^{6}$ to $10^{8}$ cells/L $[13,14]$. While these high bacterial counts are generally considered to have no direct impact on public health [9], abrupt changes in bacterial concentrations can indicate failure of disinfection or filtration, or pipe breakage, that could indicate occurrences in the treatment process or external contamination in the DWDS that could indirectly impact the consumer [7]. Detecting any sudden changes, however, requires an understanding of which bacterial counts are expected, with this knowledge generated by comprehensive monitoring of the bacterial community in a DWDS.

Conventional bacterial monitoring of process performance is largely based on enumeration of indicator bacteria, such as Escherichia coli, coliforms and heterotrophs in grab samples of water [15]. These methods are labor- and resource-intensive and thus expensive. In addition, these methods detect only specific fractions of the bacterial community [16], limiting their resolution for detailed studies of bacterial regrowth in a DWDS [7]. Flow cytometry (FCM) has been proposed as a modern, rapid, standardized, and increasingly used alternative detection method for bacteria in drinking water [13,17]. This laser-based method rapidly, accurately, and reproducibly determines the concentration of bacteria in a water sample $[18,19]$, and can also be used to measure the number of intact cells within the total population to assess the effectiveness of some treatments, such as chlorination [20]. Changes in the type of bacteria within the community are assessed by observing fluctuations in the distribution of DNA within the cells; for example, by comparing the distribution of cells across populations defined by the user (gates), such as high nucleic acid (HNA) bacteria and low nucleic acid (LNA) bacteria [14].

While there is broad consensus regarding typical values from source to tap for FCM-based bacterial concentrations in drinking water, specific baselines and the range of fluctuations around these baselines that are consistent with safe water need to be established for each DWDS individually. This requires large data sets collected from the drinking water treatment and distribution systems of interest. These need to define routine values, to describe proper functioning of the whole system, and identify how, and to what degree, fluctuations in these values reflect abnormalities and can describe the success of corrective actions. Baselines generated by permanent surveillance of routine operations may also be valuable for planning and monitoring changes in the treatment or distribution of water.

In this study, the process of establishing FCM baselines for a drinking water treatment and distribution system is described. Historically, Kvarnagården DWTP in Varberg, Sweden had limited treatment of surface water and very high cell concentrations $\left(7 \times 10^{5}\right.$ cells $\left./ \mathrm{mL}\right)$ of bacteria in the DWDS. In November 2016, the DWTP was upgraded to ultrafiltration (UF) membranes, combined with flocculation, reducing the input of bacterial cells into the DWDS and removing about $50 \%$ of natural, especially high molecular weight, organic carbon $[2,21]$. This upgrade was closely monitored with FCM and showed that bacterial concentrations in treated and distributed water were substantially lowered by the change in treatment processes [2]. With extremely low numbers of bacteria contributed by the treatment plant, the contribution of cells from biofilms in the DWDS to the total bacterial concentrations was observed, and the low bacterial concentrations at several monitoring locations in the DWDS indicated that concerns about an initial massive detachment of biofilm due to the changes in treatment were unwarranted [1,2].

To further monitor the biofilm over a longer time period, and to expand the application of FCM monitoring in this DWDS, additional sampling locations at greater distances and incorporation of different hydrodynamic and material properties in the DWDS were examined. The extensive sampling campaign of the selected sampling points was conducted over 12 months.

The objectives of this study were to:

(1) Confirm that the biofilm did not detach in the long-term.

(2) Assess the impact of seasonal changes on cell concentrations.

(3) Obtain detailed, spatially resolved information throughout the DWDS. 
(4) Gather insights on driving environmental and/or technical factors of cell concentrations.

\section{Materials and Methods}

\subsection{Study Site and Sampling}

The study location, a DWDS in Varberg, Sweden operated by the utility VIVAB, is comprised of roughly $580 \mathrm{~km}$ of pipes, of which the majority are polyvinyl chloride $(35 \%)$ and polyethylene (20\%). This DWDS distributes approximately 5 million $\mathrm{m}^{3}$ water annually to 60,000 residents, and is produced from surface water by the DWTP Kvarnagården. The treatment process consists of rapid sand filtration, UF combined with a coagulation step, $\mathrm{pH}$ adjustment, and disinfection with UV and chloramine (between 0.13 and $0.21 \mathrm{mg} / \mathrm{L}$; Supplementary Materials Figure S1). Eighteen different locations were sampled from April 2018 to April 2019, beginning approximately one and a half years after the installation of the UF membrane at the DWTP in November 2016. This included the UF membrane treatment process (feed water, permeate) and the outgoing water from the DWTP with 15 points located in the DWDS (Supplementary Materials Figure S2). In total, 510 samples were taken and analyzed at two-week sampling intervals, with weekly sampling during July and September and no sampling during August. All water samples were collected in sterile $15 \mathrm{~mL}$ Falcon tubes with the addition of $1 \%(v / v)$ sodium thiosulphate $(20 \mathrm{~g} / \mathrm{L})$ for quenching residual chlorine. The sampling routine included burning off the tap and flushing the line for $10 \mathrm{~min}$ before sampling and recording of water temperature. Samples were transported in cooling boxes and analyzed by FCM the same day.

\subsection{FCM Analysis}

FCM analysis was performed on a BD Accuri C6 Flow Cytometer (BD Biosciences, Belgium) with a $50 \mathrm{~mW}$ argon laser, wavelength $=488 \mathrm{~nm}$ [22]. Fluorescence from SYBR ${ }^{\circledR}$ Green I (Invitrogen AG, Switzerland) and propidium iodide were read at $533 \pm 30 \mathrm{~nm}=$ FL1 (green fluorescence) and $>670 \mathrm{~nm}$ = FL3 (red fluorescence), respectively. The flow rate was $35 \mu \mathrm{L} / \mathrm{min}$ with a threshold of 500 arbitrary units of green fluorescence. Samples were stained with $5 \mu \mathrm{L}$ of SYBR Green I at 100× diluted with dimethyl sulphoxide in a total volume of $500 \mu \mathrm{L}$ corresponding to $1 \times$ SYBR Green I final concentration and incubated in the dark for $15 \mathrm{~min}$ at $+37^{\circ} \mathrm{C}$. When included, the concentration of propidium iodide was $0.3 \mathrm{mM}$ (Sigma-Aldrich, Germany). Identical gates were applied for both types of staining (intact cell count (ICC) and total cell count (TCC)).

\subsection{Other Water Quality Parameters}

Total chlorine was analyzed using a SL1000 Portable Parallel Analyzer (Hach, Düsseldorf, Germany). Water temperature was measured with a TD 10 Thermometer (VWR, Radnor, PA, United States). TOCeq was measured online using a s::can (i::scan ${ }^{\mathrm{TM}}$; s::can Messtechnik GmbH, Vienna, Austria) with wavelength range $230-350 \mathrm{~nm}$. The online absorbance measurements were calibrated against laboratory TOC analyses from the laboratory to calculate TOCeq.

\subsection{Data Analysis}

For FCM, manual gating strategies and a pattern analysis approach were applied. FCM fingerprints, including ratios of LNA and HNA bacteria, were compared and analyzed using the single cell analysis software FlowJo (Treestar, Inc., San Carlos, CA, USA). CHIC analysis (CHIC: Cytometric Histogram Image Comparison) was used for pattern analyses using R packages flowCHIC and flowCore [23-25]. FCM scatterplots were converted into $300 \times 300$ pixel images with 64 -channel gray scale resolution for image comparison. The values generated by CHIC describing the differences between water samples were visualized using a non-metric multidimensional scale (NMDS) plot based on Bray-Curtis dissimilarity to capture changes in bacterial community structure $[23,24]$. To simplify correlations, the envfit function for environmental vectors was applied using R software [26]. 
The contact area between water and biofilm was determined by calculating the ratio between lateral surface and water volume for each pipe segment (Equation (1)).

$$
\text { Contact area }=\frac{2 \Pi r h}{\Pi r 2 h}
$$

Hydraulic modeling using MIKE Urban (DHI) was applied to determine specific retention times for different pressure zones in the DWDS.

\section{Results and Discussion}

\subsection{Long-Term Stability After an Upgrade of the Treatment Process}

The implementation of UF combined with coagulation at the DWTP Kvarnagården in Varberg led to a significant change in water quality $[2,27]$. TCC was reduced by a factor of $10^{3}$ cells $/ \mathrm{mL}$ and about $50 \%$ of natural organic carbon, especially the high molecular weight fraction was removed by direct coagulation over the UF membranes (Figure 1). Before the changes in the treatment process, the number of bacteria in the water was approximately $660,000 \pm 7000$ cells/mL regardless of sampling site and time. After installation of the new process, TCC diminished to about 27,500 \pm 9600 cells $/ \mathrm{mL}$ at all sampling points, reaching a low of $3400 \pm 2000$ cells/mL in February 2017. TCC in the outgoing drinking water continued to decrease to about $350 \pm 170$ cells/mL in March 2018, giving a 1000-fold reduction of TCC in produced drinking water due to installation of UF. TCC determined for an expanded number of DWDS sampling points from April 2018 until April 2019 showed consistent and expected cell counts at all sampling points, subject to seasonal variations, and no large, rapid changes in TCC in the water phase that could indicate detachment of biofilm [20].

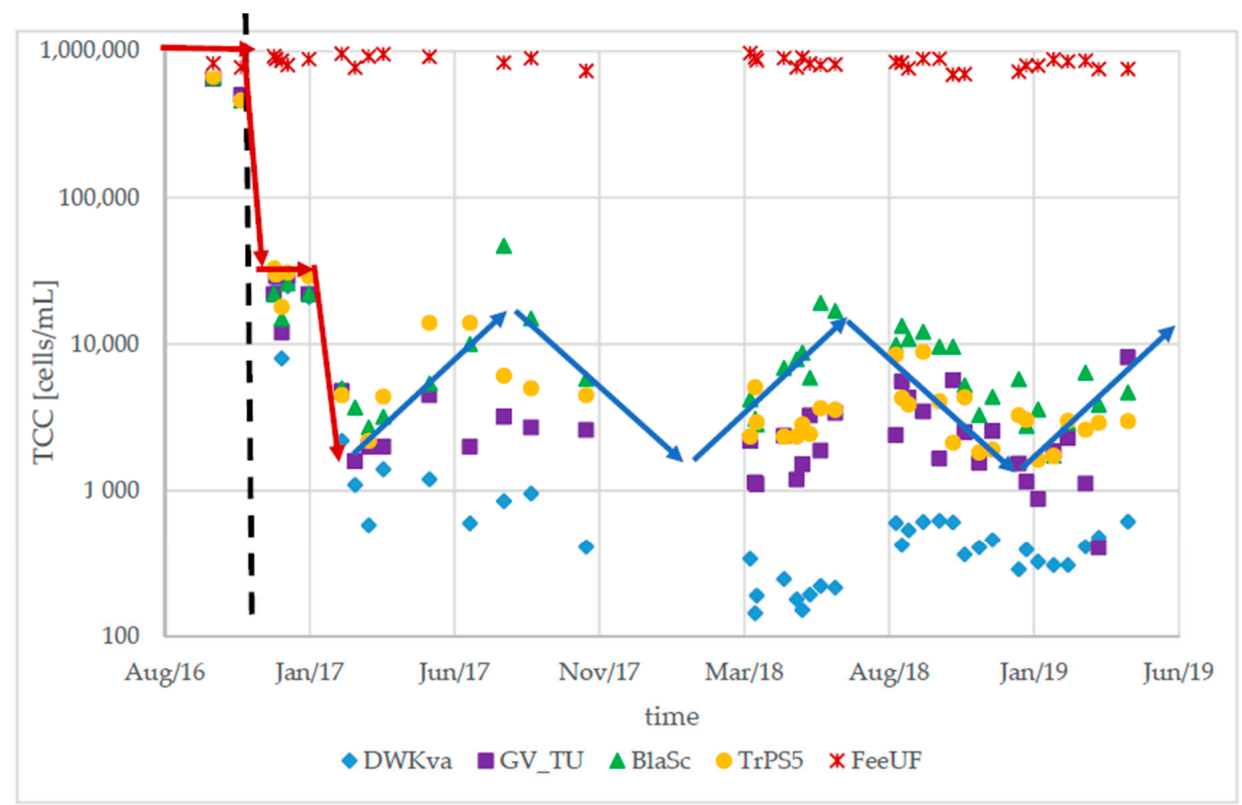

Figure 1. Total cell count (TCC) in water from the drinking water treatment plant (DWTP) and drinking water distribution system (DWDS). TCC was measured in the feed water to the ultrafiltration (UF) membrane (FeeUF, red stars); outgoing drinking water (DWKva, blue diamonds); and distributed water at an office building located at WWTP Getteröverket (GV_TU, purple squares), a public school in Bläshammar (BlaSc, green triangles), and a pump station in Trönningenäs (TrPS5, yellow circles). Measurements were taken before and after the installation of UF, indicated by the vertical dashed line. The red arrows show changes of TCC before, during, and shortly after commissioning of UF; blue arrows indicate seasonal changes in TCC. The graph includes published data (until January 2017, [2]). 


\subsection{Seasonal Changes in the Bacteral Community}

The extended sampling program took place from April 2018 to April 2019 (Supplementary Materials Figure S2). Water temperatures increased at all sampling points during the summer, as expected, from $6.68 \pm 1.28{ }^{\circ} \mathrm{C}$ in April 2018 to $13.68 \pm 2.83{ }^{\circ} \mathrm{C}$ in September 2018, an increase of $6.99 \pm 2.30{ }^{\circ} \mathrm{C}$ (Supplementary Materials Figure S3).

The average TCC during April 2018, considering all DWDS sampling points, was $3.1 \times 10^{4} \pm$ $3.6 \times 10^{4}$ (range: $3 \times 10^{2}$ to $1.1 \times 10^{5}$ cells $/ \mathrm{mL}$ ). This increased in summer to an average TCC of $1.0 \times$ $10^{5}$ cells $/ \mathrm{mL}$ (range: $5 \times 10^{2}$ to $4 \times 10^{5}$ cells $/ \mathrm{mL}$ ), an average 3.35 -fold increase (range: $1.51-5.24$-fold increase; Supplementary Materials Figure S3). This may be partially explained by regrowth of bacteria due to the elevated water temperatures during summer.

To demonstrate the observed seasonal shifts, values obtained from water collected at sampling point Masar showed TCC fluctuating with changes in water temperature with an increase of TCC during the summer months (Figure 2). The TCC in the outgoing water from the DWTP also increased during this period, from $230 \pm 70$ cells/mL in April to $540 \pm 80$ cells/mL in September (temperature increase from 5.8 to $7.5^{\circ} \mathrm{C}$ ). At Masar, the TCC was 24,400 \pm 330 cells $/ \mathrm{mL}$ in April with a water temperature of $6.3{ }^{\circ} \mathrm{C}$. The water temperature at this sampling point increased to $14.9{ }^{\circ} \mathrm{C}$ and TCC increased by 4 -fold to 98,300 \pm 1200 cells/mL. By April 2019, TCC had returned to 23,350 \pm 300 cells $/ \mathrm{mL}$ with a water temperature of $6.2^{\circ} \mathrm{C}$, showing a clear seasonal trend. The ratio of intact bacteria in the water at Masar also fluctuated seasonally, from $69 \pm 1 \%$ intact cells in April to $86 \pm 2 \%$ in September, with an increase in intact cells supporting the observation that increases in TCC during these months are due to bacterial growth.

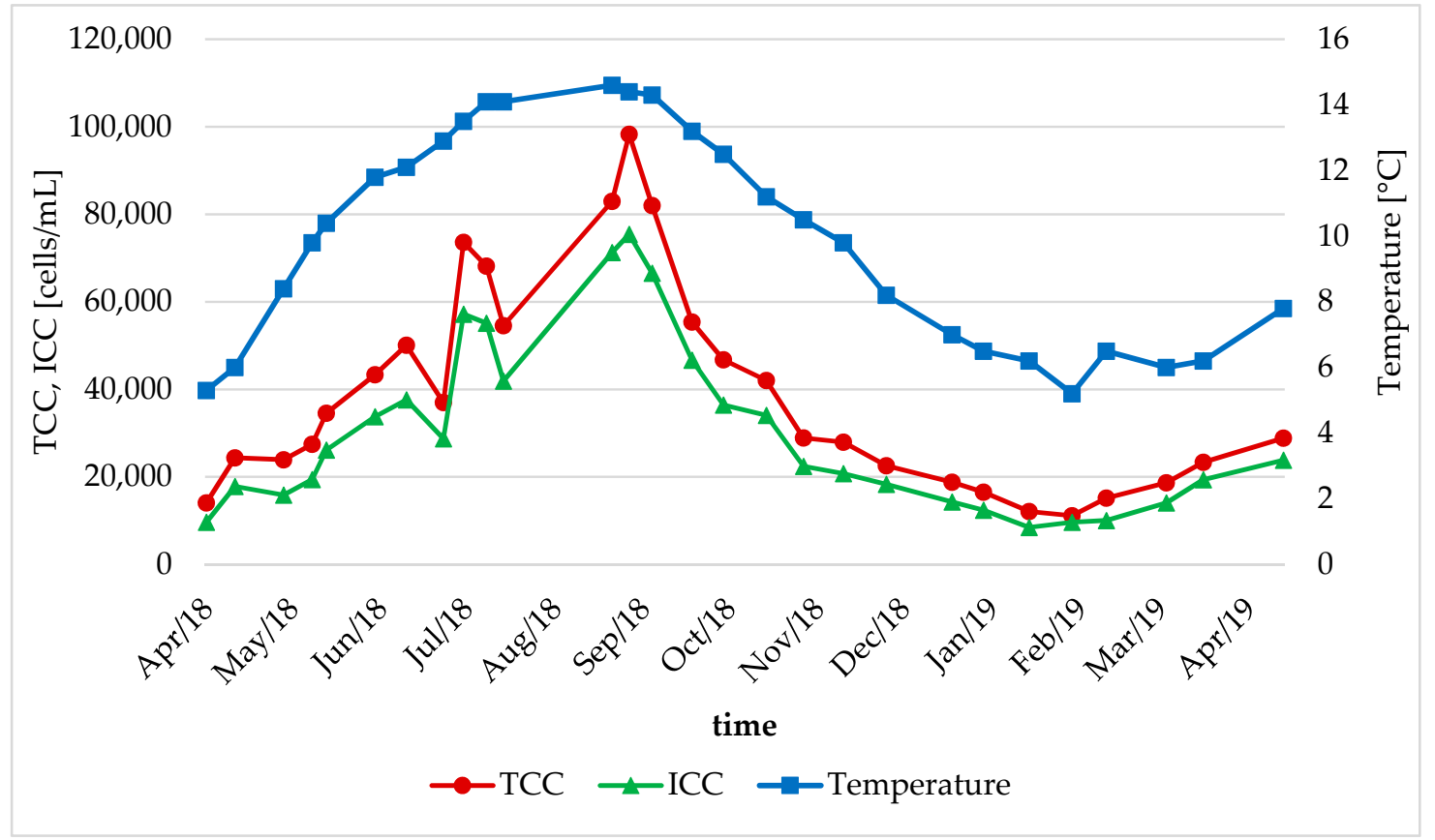

Figure 2. Changes in TCC (red line, circles), intact cell count (ICC) (green line, triangles), and water temperature (blue line; squares) at sampling point Masar. A clear seasonal trend, with increases in TCC and water temperature during the summer period, is shown.

The bacterial community, indicated by nucleic acid content described by FCM, also changed with season. The bacterial population gradually shifted to greater numbers of bacteria described as LNA during the summer months (Figure 3). Analyses from later months indicated a return of the bacterial community to a previous state (both in TCC and community structure, data not shown). A study from 2014 showed equal temporal trends in the microbial community that indicate annual 
reproducibility [28]. The histograms shown in Figure 3 represent individual FCM fingerprints of microbial communities. The amount of DNA in a single bacteria cell is described by its position along the x-axis. Cells registering with higher green fluorescence contain increasing amounts of DNA [22].

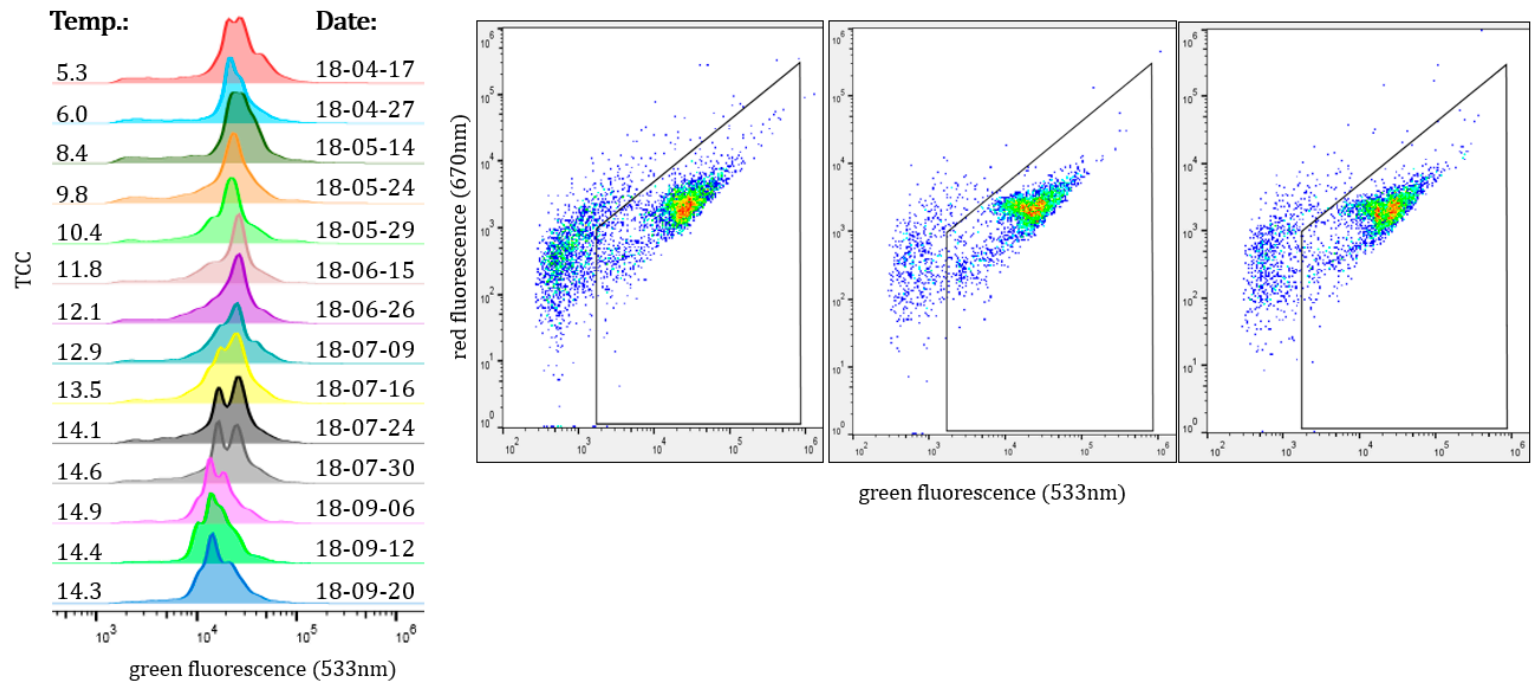

Figure 3. Changes in the bacterial community over season at Masar. FCM fingerprints (left panel) from sampling in April 2018 to September 2018 show a shift to increasing proportions of low nucleic acid (LNA) bacteria, likely due to an increase in water temperature during summer. Scatterplots (right panel) show individual cells within the population, the gate applied, and a gradual increase in intensity corresponding to more cells with LNA (sampling date for left to right: 27/04/18; 16/07/18; 24/07/18).

As expected, more bacterial growth (regrowth) was observed when the temperature in the water rose. Increasing TCC and temperature were also observed at Tofta, Tronn, and BlaSc, with $7000 \pm 6200$ cells $/ \mathrm{mL}$ and water temperature: $7.2 \pm 1.4{ }^{\circ} \mathrm{C}$ during spring, rising to $34,300 \pm 28,000$ cells $/ \mathrm{mL}$ and water temperature: $15.5 \pm 2.1^{\circ} \mathrm{C}$ during summer $(5.16 \pm 0.89$-fold increase in TCC; Supplementary Materials Figure S3). Seasonal changes for bacterial communities in DWDS have been observed in previous studies, and indicate reproducible annual patterns [28-30]. However, in the current study, some sampling points did not show this expected trend. Water from Hunst, Himle, Godst, and Lofta had a high TCC during spring (Supplementary Materials Figures S3 and S5) and an increase in water temperature had only a moderate impact on the TCC. TCC at these points increased from 55,400 $\pm 14,700$ cells/mL (water temperature: $7.2 \pm 0.3^{\circ} \mathrm{C}$ ) during spring to $156,200 \pm 38,600$ cells/mL (water temperature: $15.8 \pm 0.8^{\circ} \mathrm{C}$ ) during summer, giving only a $2.84 \pm 0.13$-fold increase associated with the warmer water temperatures. Water from sampling point TrPS5, despite having an increase in water temperature of $7.1^{\circ} \mathrm{C}$ (from 5.6 to $12.7^{\circ} \mathrm{C}$ ), increased TCC by only a factor of 1.79 (from $2900 \pm 70$ to $5200 \pm 100$ cells/mL; Supplementary Materials Figure S6). The apparent decoupling between temperature and TCC at this specific sampling location maybe be due to a combination of the low retention time and the short distance between the sampling point and the DWTP, which together would prevent significant accumulation of bacteria, either from regrowth or cells leaving the biofilm, to the water [2].

\subsection{Detection of Abnormalities Within the DWDS Using TCC Baselines}

Baselines were defined for each water sampling point in the study by grouping months with similar TCC values (standard deviation $\leq 25 \%$ ) and then calculating average TCC values for those periods. Warning and alarm limits were determined to describe tailored acceptable TCC values for each sampling point and period. Applications of these defined baselines detected an abnormality within the DWDS in late June 2019. During routine sampling, the TCC at sampling point TrPS5 was 717,000 cells $/ \mathrm{mL}$, exceeding the alarm limit of 15,000 cells/mL for this location (Supplementary 
Materials Figure S7). Consultations with the personnel responsible for the DWDS revealed that maintenance work had occurred near TrPS5 in March 2019 and further investigation discovered that a valve near this sampling point had been accidentally closed. This resulted in insufficient circulation of the water, and possibly bacterial regrowth due to stagnation, and provided a likely explanation for the increased TCC [14]. The TCC returned to normal after the opening of the valve. While the most likely explanation for the increase in TCC is bacterial growth, additional explanations could include increased detachment of biofilm due to altered fluid dynamics in the pipe [31] or increased contact time of the stagnant water with the biofilm [32].

\subsection{Relationship of the Bacterial Population to Contact Time with Biofilm}

Possible correlations between TCC, \%HNA, \%ICC, and characteristics of the DWDS were evaluated using CHIC in combination with the envfit function (Figure 4). CHIC analysis compares individual FCM scatterplots describing the bacterial community in water samples. The comparisons are presented as a non-metric multidimensional scale (NMDS) plot, with water samples containing similar bacterial content shown as two dots that are close to each other, and water samples with more dissimilar bacterial content in the water placed further away from each other. This enables a visual determination of changes in the different bacterial communities, with the content of all water samples in one study presented in the same plot. The addition of vector analysis enables visualization of correlations between the bacterial communities, as determined by FCM, and environmental parameters. Longer vectors indicate stronger correlations, and those pointing in opposite directions indicate negative correlations.

Correlations between TCC and retention time, and TCC and the contact area between biofilm and the water, were determined using three data sets for each sampling point (Supplementary Materials Table S1). TCC increased with increasing retention time, as well and increasing contact area (Figure 4A). There was a negative correlation between retention time and \%HNA bacteria. The amount of HNA bacteria in the water samples decreased with an increase in retention time. These results were confirmed by a more detailed examination using a subset of samples selected from the range of $0-50$ in the NMDS in Figure 4A. This reduced the influence from outliers, such as samples with, for example, a high retention time (Figure 4B). When fewer samples were included in the analysis, the relationship between the correlations of \%HNA and retention time shifted slightly (Figure 4B). However, more precise analyses are necessary to confirm these assumptions.

The sampling points are connected to the DWTP by $87.7 \mathrm{~km}$ pipes consisting of 6 different pipe materials with a total pipe surface area of $79,900 \mathrm{~m}^{2}$. Water from sampling points at a greater distance from the DWTP usually had a higher TCC than water sampled closer to the DWTP (Supplementary Materials Figure S3). During April 2018, water leaving the DWTP contained $230 \pm 70$ cells/mL; water from close to the DWTP (GV_TU, BlaSc) contained $2250 \pm 990$ cells $/ \mathrm{mL}$ and a more distant sampling point (Björk) had water containing 113,200 \pm 4100 cells/mL. One explanation for the increased cell counts with respect to distance was the increased contact time between the water and the pipe surface biofilm [2]. The contact area between the water and biofilm was then determined by incorporating both pipe lengths and diameters to examine the relationship between TCC and the contact area/mL (Figure 5). This identified a positive correlation between the number of cells in the water and the contact area provided by the pipe biofilm (correlation coefficient $R=0.75 ; p=0.0008$ ). 

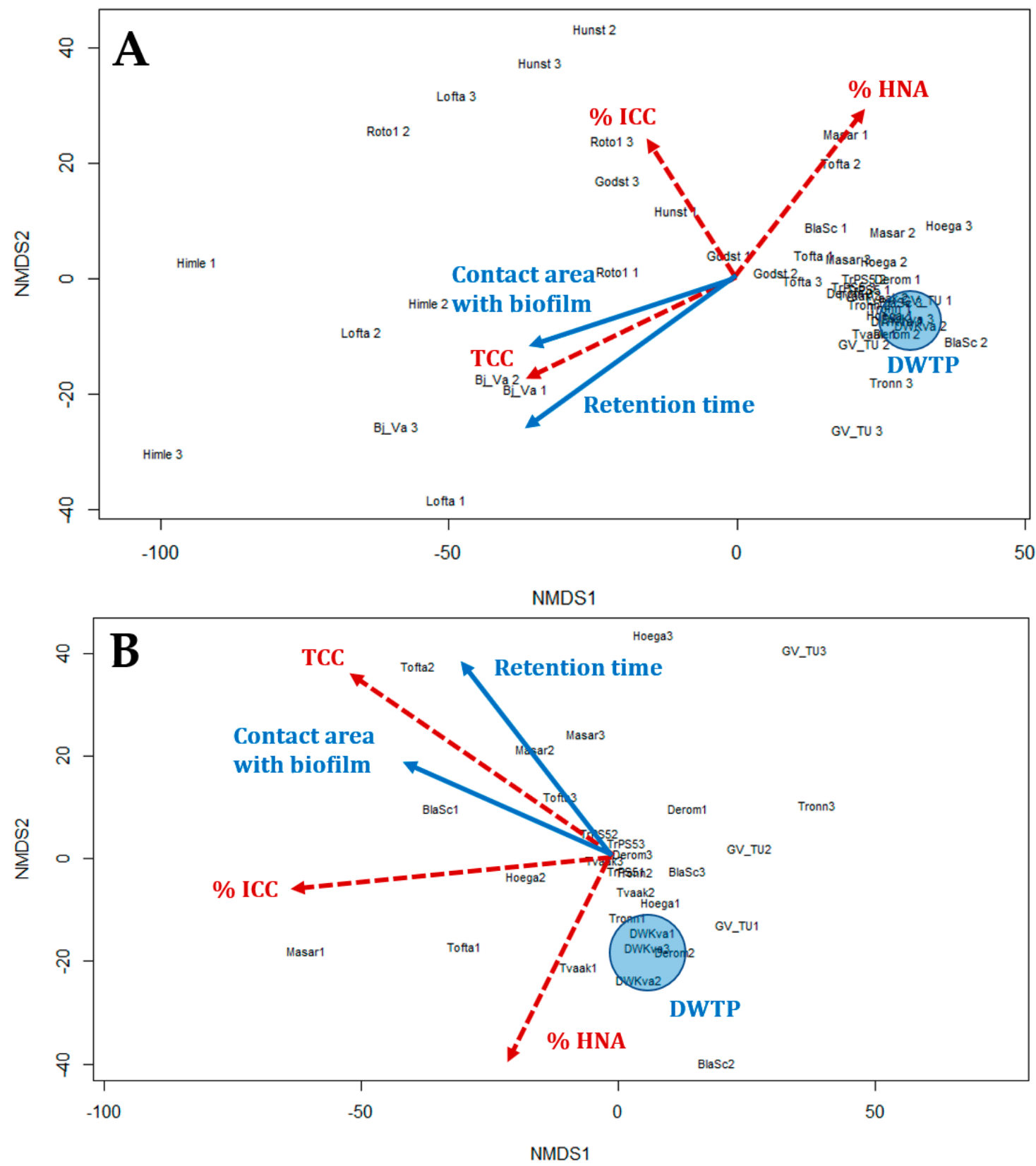

Figure 4. Output from CHIC analysis plot combined with envfit showing correlations (red dotted arrows: Bacterial community parameters; blue arrows: Distribution system parameters). Samples that are close to each other in the plot have similar bacterial profiles by FCM; vectors indicate possible correlations. (A) Analysis of 16 sampling points ( $n=3$ for each sampling point) sampled during April and May 2018. (B) Analysis of 10 sampling points, selected from the 16 in (A) ( $n=3$ for each sampling point) sampled during April and May 2018. Using the smaller subset of samples permitted a more detailed examination of the correlations shown in panel (A) (NMDS1 range $=0-50$ ).

Chlorine residues can influence microbial regrowth, which also changes with retention time and pipe length $[29,33]$. In this study, water leaving the DWTP contained on average $0.19 \pm 0.02 \mathrm{mg} / \mathrm{L}$ chloramine; however, as expected, these chloramine concentrations were not present at all points in the distribution system (Supplementary Materials Figure S4). With the exception of a few sampling points close to the DWTP, the total chlorine concentration was below $0.04 \mathrm{mg} / \mathrm{L}$ at all other sampling points, and thus below the detection limit. A lack of chlorine can lead to faster regrowth of bacteria [33], and a free chlorine concentration of at least $0.3 \mathrm{mg} / \mathrm{L}$ is required to prevent bacterial regrowth in 
the distribution system [9]. The only impact that was observed was an inverse correlation between the intact cell concentration and chloramine concentration, with intact cell concentration elevated at sampling points where the total chlorine concentration was below $0.05 \mathrm{mg} / \mathrm{L}$ (Supplementary Materials Figure S4).

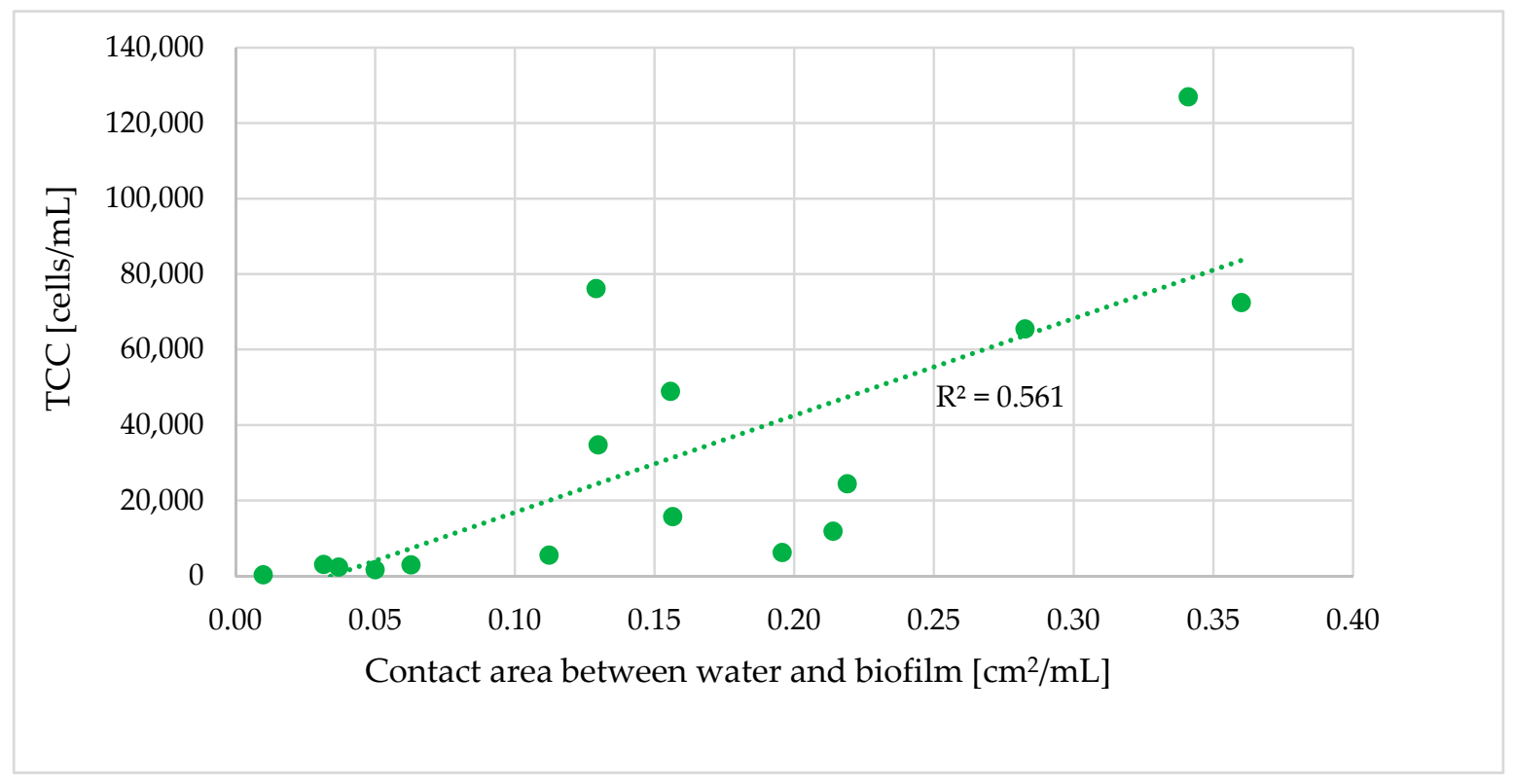

Figure 5. Correlation between the contact area for biofilm and water, and TCC.

This suggests that while changes in chlorine influenced whether the bacteria were intact or not, most of the bacterial dynamics between the water and biofilm observed in the current study as increases in TCC or changed \%HNA are not due to loss of chlorine. Instead, a continuous interaction between the water and the biofilm, with the growth and release of bacteria from biofilm, provides a gradually accumulating supply of planktonic bacteria that can be monitored by FCM in the bulk water. A previous study calculated that it takes 2.31 days to double the number of planktonic bacteria in a bioreactor-based model system for DWDS at $13{ }^{\circ} \mathrm{C}$ without chlorine [34]. This can be extrapolated to suggest that for growth of the bacteria released from the biofilm, a retention time of at least 55 hours is required to double their number, and at shorter times, changes in the bacterial content of the water must be attributed to addition of cells from biofilm [2]. It should, however, be noted that monitoring of the biofilm by FCM was possible in this current study, and could be applied in other DWDS for inferring biofilm interactions, because the input of cells from the treatment plant is minimal [2]. When the number of cells in the outgoing drinking water is high, due to processes in the DWTP such as biological filtration, the resolution of FCM prevents detailed descriptions of bacteria only entering the water from DWDS biofilm or regrowth.

Prolonged stagnation of water has been associated with significant growth [34], and longer retention times also contribute to increased bacterial growth in the DWDS [9]. In this study, retention time had a significant impact on the bacterial community in the water, impacting both TCC and \%HNA bacteria (Figure 6). 


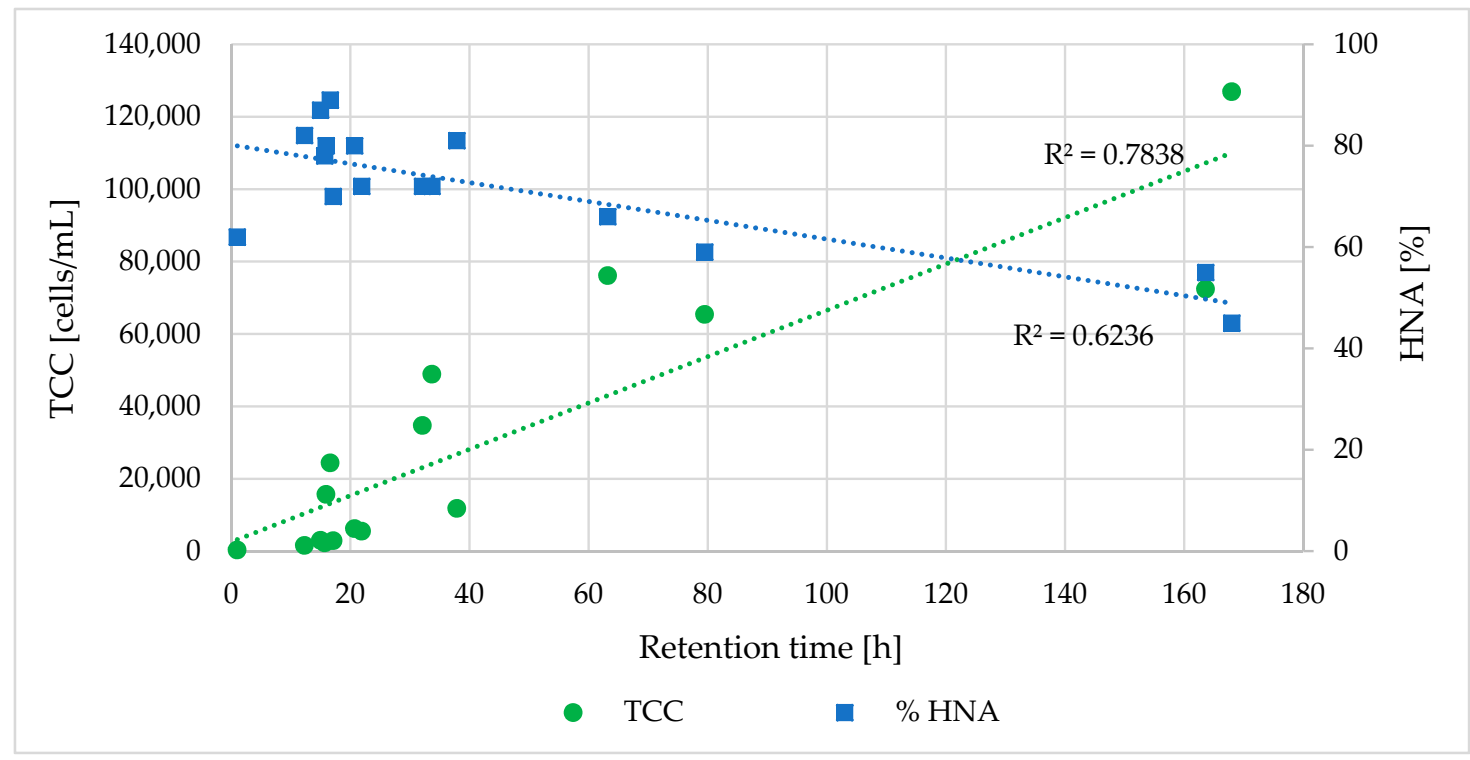

Figure 6. Correlation between retention time and TCC (green dots), as well as \%HNA bacteria (blue squares).

An increased contact time between biofilm and water increased the number of bacteria (correlation coefficient $R=0.89 ; p<0.0001$ ). This could be due to an increased time during which the bacteria can detach from the biofilm and accumulate in the water phase, or an increased retention time could also provide bacteria in the water the chance to multiply [35]. Higher retention times were also correlated with a decrease in the \%HNA bacteria, from about $80 \%$ for water with a retention time below $20 \mathrm{~h}$ to $50 \%$ when retention time exceeded $160 \mathrm{~h}$ (correlation coefficient $R=-0.79 ; p=0.0003$ ). Differences in community structures for water samples with disparities in retention time and distance from the DWTP have been observed in previous studies [28]. One recent study showed a predominance of LNA bacteria in branch ends of DWDSs, which indicates similar trends compared to the results of this study [36]. Interestingly, this strong negative correlation between retention time and \%HNA bacteria was not observed when \%HNA were examined with respect to contact area. Studies show that LNA, as well as HNA, bacteria are able to grow in oligotrophic water [37]. Drinking water is an oligotrophic environment with total organic carbon (TOC) concentrations below $1 \mathrm{mg} / \mathrm{L}$ [36], and the DWDS in the current study was no exception: TOCeq measured in the permeate from the UF membrane showed stable and relatively low TOCeq values of about $1.83 \pm 0.31 \mathrm{mg} / \mathrm{L}$ from April 2018 until April 2019 (Supplementary Materials Figure S8). Those values are comparable with the TOCeq values for the outgoing drinking water. This could explain why, in this DWDS, the \%HNA bacteria decreased with retention time. While the specific growth rate of LNA bacteria is lower compared to the specific growth rate of HNA bacteria, suggesting that regrowth of HNA bacteria in the DWDS should be favored [37], LNA bacteria could predominate with increased retention time if the mechanism by which bacteria entering the water is not due to growth. This supports the conclusions made by Chan et al. that it is bacteria entering the water from the biofilm that are the predominant source of bacteria in this distributed water [2]. This is supported by the observation that contact area is only correlated with increasing TCC, and not with any change in \%HNA, suggesting that the community of bacteria leaving the biofilm and entering the water has a consistent composition which is not altered by location of the biofilm in the DWDS. Perhaps the water quality in this DWDS selects which bacteria leave the biofilm at different locations, since presumably there are diverse biofilm populations within the DWDS, due to the presence of different pipe materials [38]. 


\section{Conclusions}

Using FCM, it was possible to capture the annual dynamics of the biofilm in this DWDS, quantifying changes in TCC, percentage of intact cells, and changes in the community composition, reflected in the amounts of LNA and HNA bacteria. The seasonal changes indicated an annual reproducibility and allowed the determination of baselines for different points in the DWDS.

The major findings of this study are:

1. The bacterial community in the DWDS experienced clear seasonal changes with similar patterns for different areas of the DWDS. An increase in water temperature led to a significant increase in TCC during the summer period (range: 1.51-5.24-fold increase) at some locations.

2. Hydraulic and specific pipe conditions influence the bacterial community in the water. FCM results indicated that an increase in retention time led to a decrease in the \%HNA bacteria in the drinking water (correlation coefficient $R=-0.79$ ).

3. Longer retention times and increased contact between the water and pipe biofilm led to an increase in TCC. Significant differences in the TCC could be seen in different areas of the DWDS depending on distance from the DWTP and retention time.

\section{Limitations and Future Perspectives}

In this, and other studies, the combination of various water treatments processes in the DWTP, and different conditions even within an individual DWDS, complicates the formulation of general statements regarding the microbiology in the water [1]. This necessitates the examination of each DWDS individually and the determination of baselines in a seasonal context. As changes of the bacteria in the drinking water are influenced by exchange between water and biofilm in the pipes [39] and regrowth due to changes in residual disinfectant concentration or substrate availability [40], determining how each factor contributes at different locations and seasons is difficult. One influence can be favored by different attributes of the heterogeneous features of the DWDS such as pipe dimensions, pipe material, and water path, as well as retention time which varies depending on local water demand [28]. In this context, the current study is limited, only indicating the complexity of the bacterial content in the water, and indirectly the impact of biofilm from the DWDS. Further investigations are needed to advance our understanding of, for example, the impact of nutrients on the biofilm, in order to generate new and detailed insights into the role played by microbiology in environmental engineering.

The main purpose of this study was to compile a comprehensive description of temporal and spatial bacterial dynamics in the drinking water, and indirectly, the biofilm. This resulted in the preliminary definitions of baselines for microbiological water quality in different zones in this DWDS, providing a new and essential strategy for enhanced drinking water management in this system. Future monitoring incorporating these baselines can be used to detect abnormalities and sudden changes in the bacterial content of the water that may occur due to malfunctions, water leakages, or pipe maintenance, as well as ensuring that values return to the baselines to indicate recovery of acceptable water quality in the DWDS. The possibility to rapidly identify changes in the number of bacteria in the water, and any altered pattern of regrowth, becomes even more important with regard to a possible removal of chloramine in this DWDS in the future. The use of FCM to monitor the status of the distributed water can contribute to managing the uncertainty of how the removal of the disinfectant will affect bacterial regrowth in the pipes, as results can be rapidly available and compared to robust baselines for surveillance. However, the lack of disinfectant residual makes proper engineering practices in operation, maintenance, and construction of distribution networks vital in order to protect the drinking water quality [41].

Supplementary Materials: The following are available online at http://www.mdpi.com/2073-4441/11/10/2137/s1: Figure S1: Old and new treatment process at Kvarnagården DWTP in Varberg, Sweden; Figure S2: Water sampling points in the DWDS in Varberg, Sweden; Figure S3: Schematic description of TCC in the DWDS, and increase of TCC and water temperature from spring to summer; Figure S4: Intact cell count in connection with residues of 
chloramine in the DWDS in $\mathrm{mg} / \mathrm{L}$; Figure S5: Changes in TCC, ICC, and water temperature at sampling point Hunst; Figure S6: Changes in TCC, ICC, and water temperature at sampling point TrPS5; Figure S7: Increase in TCC at sampling point TrPS5 in late June 2019; Figure S8: TOCeq measured in the permeate of the UF membrane from April 2018 to April 2019; Table S1:Flow cytometry results and environmental parameters for different sampling points.

Author Contributions: Conceptualization, All; methodology, All; formal analysis, C.S. and P.R.; investigation, C.S.; writing - original draft preparation, C.S., P.R., M.D.B. and A.K.; writing-review and editing, All; visualization, C.S., K.P. and S.C.; supervision, A.K.; project administration, A.K.; funding acquisition, A.K., P.R. and C.J.P.

Funding: This research received external financial support of the Biofilm study-project (Project no. 17-104) funded by The Swedish Water and Wastewater Association (Swedish Water Development, SVU).

Acknowledgments: The authors acknowledge the financial support from Vatten \& Miljö I Väst AB, which funded this long-term study, including monitoring program and analyses.

Conflicts of Interest: The authors declare no conflicts of interest.

\section{References}

1. Chan, S. Processes Governing the Drinking Water Microbiome. Ph.D. Thesis, Faculty of Engineering (LTH), Lund, Sweden, 2018.

2. Chan, S.; Pullerits, K.; Keucken, A.; Persson, K.M.; Paul, C.J.; Rådström, P. Bacterial release from pipe biofilm in a full-scale drinking water distribution system. NPJ Biofilms Microbiomes 2019, 5, 9. [CrossRef] [PubMed]

3. Liu, G.; Zhang, Y.; van der Mark, E.; Magic-Knezev, A.; Pinto, A.; van den Bogert, B.; Liu, W.; van der Meer, W.; Medema, G. Assessing the origin of bacteria in tap water and distribution system in an unchlorinated drinking water system by SourceTracker using microbial community fingerprints. Water Res. 2018, 138, 86-96. [CrossRef] [PubMed]

4. Waak, M.B.; Hozalski, R.M.; Hallé, C.; Lapara, T.M. Comparison of the microbiomes of two drinking water distribution systems-With and without residual chloramine disinfection. Microbiome 2019, 7. [CrossRef] [PubMed]

5. Feron, D.; Neumann, E. “Biocorrosion 2012"-From advanced technics towards scientific perspectives. Bioelectrochemistry 2014, 97, 1. [CrossRef]

6. Piriou, P.; Malleret, L.; Bruchet, A.; Kiéné, L. Trichloroanisole kinetics and musty tastes in drinking water distribution systems. Water Supply 2001, 1, 11-18. [CrossRef]

7. Van der Kooij, D.; van der Wielen, P.W.J.J. Microbial Growth in Drinking-Water Supplies: Problems, Causes, Control and Research Needs, 1st ed.; IWA Publishing: London, UK, 2013; pp. 1-32.

8. Baskerville, A.; Broster, M.; Fitzgeorge, R.B.; Hambleton, P.; Dennis, P.J. Experimental Transmission of Legionnaires' Disease by Exposure to Aerosols of Legionella Pneumophila. Lancet 1981, 318, 1389-1390. [CrossRef]

9. Bartram, J.; Cotruvo, J.A.; Exner, M.; Fricker, C.; Glasmacher, A. Heterotrophic Plate Counts and Drinking-Water Safety-The Significance of HPCs for Water Quality and Human Health, 1st ed.; IWA Publishing: London, UK, 2003; pp. 80-118.

10. Pinto, A.J.; Xi, C.; Raskin, L. Bacterial community structure in the drinking water microbiome is governed by filtration processes. Environ. Sci. Technol. 2012, 46, 8851-8859. [CrossRef]

11. Hijnen, W.A.M.; Beerendonk, E.F.; Medema, G.J. Inactivation credit of UV radiation for viruses, bacteria and protozoan (oo)cysts in water: A review. Water Res. 2006, 40, 3-22. [CrossRef]

12. Douterelo, I.; Boxall, J.B.; Deines, P.; Sekar, R.; Fish, K.E.; Biggs, C.A. Methodological approaches for studying the microbial ecology of drinking water distribution systems. Water Res. 2014, 65, 134-156. [CrossRef]

13. Hammes, F.; Berney, M.; Wang, Y.; Vital, M.; Köster, O.; Egli, T. Flow-cytometric total bacterial cell counts as a descriptive microbiological parameter for drinking water treatment processes. Water Res. 2008, 42, $269-277$. [CrossRef]

14. Lautenschlager, K.; Boon, N.; Wang, Y.; Egli, T.; Hammes, F. Overnight stagnation of drinking water in household taps induces microbial growth and changes in community composition. Water Res. 2010, 44, 4868-4877. [CrossRef] [PubMed]

15. Payment, P.; Trudel, M.; Plante, R. Elimination of viruses and indicator bacteria at each step of treatment during preparation of drinking water at seven water treatment plants. Appl. Environ. Microbiol. 1985, 49, 1418-1428. [PubMed] 
16. Van Nevel, S.; Buysschaert, B.; De Gusseme, B.; Boon, N. Flow cytometric examination of bacterial growth in a local drinking water network. Water Environ. J. 2016, 30, 167-176. [CrossRef]

17. Lautenschlager, K.; Hwang, C.; Liu, W.T.; Boon, N.; Köster, O.; Vrouwenvelder, H.; Egli, T.; Hammes, F. A microbiology-based multi-parametric approach towards assessing biological stability in drinking water distribution networks. Water Res. 2013, 47, 3015-3025. [CrossRef]

18. Van Nevel, S.; Koetzsch, S.; Proctor, C.R.; Besmer, M.D.; Prest, E.I.; Vrouwenvelder, J.S.; Knezev, A.; Boon, N.; Hammes, F. Flow cytometric bacterial cell counts challenge conventional heterotrophic plate counts for routine microbiological drinking water monitoring. Water Res. 2017, 113, 191-206. [CrossRef]

19. Gatza, E.; Hammes, F.A.; Prest, E.I. White Paper: Assessing Water Quality with the BD Accuri TM C 6 Flow Cytometer. 2013. Available online: https://www.semanticscholar.org/paper/White-Paper-Assessing-WaterQuality-with-the-BD-TM-Gatza-Hammes/8e96101b49bfcb09e28425cf40c0cce2dec1afca (accessed on 18 July 2019).

20. Besmer, M.D.; Sigrist, J.A.; Props, R.; Buysschaert, B.; Mao, G.; Boon, N.; Hammes, F. Laboratory-scale simulation and real-time tracking of a microbial contamination event and subsequent shock-chlorination in drinking water. Front. Microbiol. 2017, 8, 1900. [CrossRef]

21. Keucken, A.; Heinicke, G.; Persson, K.M.; Köhler, S.J. Combined coagulation and ultrafiltration process to counteract increasing NOM in brown surface water. Water 2017, 9, 697. [CrossRef]

22. Prest, E.I.; Hammes, F.; Kötzsch, S.; van Loosdrecht, M.C.M.; Vrouwenvelder, J.S. Monitoring microbiological changes in drinking water systems using a fast and reproducible flow cytometric method. Water Res. 2013, 47, 7131-7142. [CrossRef]

23. Chan, S.; Pullerits, K.; Riechelmann, J.; Persson, K.M.; Rådström, P.; Paul, C.J. Monitoring biofilm function in new and matured full-scale slow sand filters using flow cytometric histogram image comparison (CHIC). Water Res. 2018, 138, 27-36. [CrossRef]

24. Koch, C.; Fetzer, I.; Harms, H.; Müller, S. CHIC-an automated approach for the detection of dynamic variations in complex microbial communities. Cytom. Part A 2013, 83, 561-567. [CrossRef]

25. Ellis, B.; Haaland, P.; Hahne, F.; Meur, N.L.; Gopalakrishnan, N.; Spidlen, J.; Jiang, M. FlowCore: Basic Structures for Flow Cytometry Data, Bioconductor R. Package Version 1.40.0. 2016. Available online: https://rdrr.io/bioc/flowCore/ (accessed on 7 August 2019).

26. Oksanen, J.; Blanchet, F.G.; Kindt, R.; Legendre, P.; Minchin, P.; O’Hara, R.B.; Simpson, G.; Solymos, P.; Stevens, M.H.H.; Wagner, H. Vegan: Community Ecology Package. R Package Version 2.2-1. 2015. Available online: http://CRAN.R-project.org/package=vegan (accessed on 14 August 2019).

27. Keucken, A. Climate Change Adaption of Waterworks for Browning Surface Waters: Nano- and Ultrafiltration Membrane Applications for Drinking Water Treatment. Ph.D. Thesis, Faculty of Engineering (LTH), Lund, Sweden, 2017.

28. Pinto, A.J.; Schroeder, J.; Lunn, M.; Sloan, W.; Raskin, L. Spatial-temporal survey and occupancy-abundance modeling to predict bacterial community dynamics in the drinking water microbiome. mBio 2014, 5 . [CrossRef] [PubMed]

29. Liu, S.; Gunawan, C.; Barraud, N.; Rice, S.A.; Harry, E.J.; Amal, R. Understanding, monitoring, and controlling biofilm growth in drinking water distribution systems. Environ. Sci. Technol. 2016, 50, 8954-8976. [CrossRef] [PubMed]

30. Prest, E.I.; Weissbrodt, D.G.; Hammes, F.; Van Loosdrecht, M.C.M.; Vrouwenvelder, J.S. Long-term bacterial dynamics in a full-scale drinking water distribution system. PLoS ONE 2016, 11, e0164445. [CrossRef] [PubMed]

31. Douterelo, I.; Sharpe, R.L.; Boxall, J.B. Influence of hydraulic regimes on bacterial community structure and composition in an experimental drinking water distribution system. Water Res. 2013, 47, 503-516. [CrossRef] [PubMed]

32. Lipphaus, P.; Hammes, F.; Kötzsch, S.; Green, J.; Gillespie, S.; Nocker, A. Microbiological tap water profile of a medium-sized building and effect of water stagnation. Environ. Technol. 2014, 35, 620-628. [CrossRef] [PubMed]

33. Chiao, T.H.; Clancy, T.M.; Pinto, A.; Xi, C.; Raskin, L. Differential resistance of drinking water bacterial populations to monochloramine disinfection. Environ. Sci. Technol. 2014, 48, 4038-4047. [CrossRef]

34. Boe-Hansen, R.; Albrechtsen, H.J.; Arvin, E.; Jørgensen, C. Bulk water phase and biofilm growth in drinking water at low nutrient conditions. Water Res. 2002, 36, 4477-4486. [CrossRef] 
35. Universität Göttingen. Available online: https://lp.uni-goettingen.de/get/text/4908 (accessed on 17 June 2019).

36. Liu, J.; Zhao, Z.; Chen, C.; Cao, P.; Wang, Y. In-situ features of LNA and HNA bacteria in branch ends of drinking water distribution systems. J. Water Supply Res. Technol. AQUA 2017, 66, 300-307. [CrossRef]

37. Wang, Y.; Hammes, F.; Boon, N.; Chami, M.; Egli, T. Isolation and characterization of low nucleic acid (LNA)-content bacteria. ISME J. 2009, 3, 889-902. [CrossRef]

38. Ren, H.; Wang, W.; Liu, Y.; Liu, S.; Lou, L.; Cheng, D.; He, X.; Zhou, X.; Qiu, S.; Fu, L.; et al. Pyrosequencing analysis of bacterial communities in biofilms from different pipe materials in a city drinking water distribution system of East China. Appl. Microbiol. Biotechnol. 2015, 99, 10713-10724. [CrossRef]

39. Henne, K.; Kahlisch, L.; Brettar, I.; Höfle, M.G. Analysis of structure and composition of bacterial core communities in mature drinking water biofilms and bulk water of a citywide network in Germany. Appl. Environ. Microbiol. 2012, 78, 3530-3538. [CrossRef] [PubMed]

40. Srinivasan, S.; Harrington, G.W.; Xagoraraki, I.; Goel, R. Factors affecting bulk to total bacteria ratio in drinking water distribution systems. Water Res. 2008, 42, 3393-3404. [CrossRef] [PubMed]

41. Medema, G.J.; Smeets, P.W.; Blokker, E.J.; van Lieverloo, J.H. Safe distribution without a disinfectant residual. In Microbial Growth in Drinking-Water Supplies: Problems, Causes, Control and Research Needs, 1st ed.; van der Kooij, D., van der Wielen, P.W.J.J., Eds.; IWA Publishing: London, UK, 2013; pp. 95-125.

(C) 2019 by the authors. Licensee MDPI, Basel, Switzerland. This article is an open access article distributed under the terms and conditions of the Creative Commons Attribution (CC BY) license (http://creativecommons.org/licenses/by/4.0/). 